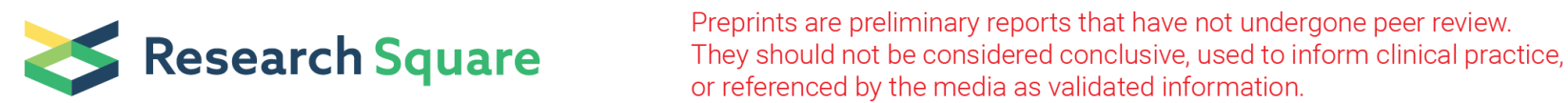

\section{Medical students' views of e-learning-based medical education during COVID-19 pandemic}

\section{Laleh Khojasteh}

Shiraz University of Medical Sciences https://orcid.org/0000-0002-6393-2759

\section{Zahra Karimian ( $\nabla$ z_karimian_z@yahoo.com )}

Shiraz University of Medical Sciences https://orcid.org/0000-0002-5631-6448

\section{Sedigheh Sharifzadeh}

Shiraz University of Medical Sciences https://orcid.org/0000-0002-2545-2949

\section{Elham Nasiri}

Shiraz University of Medical Sciences

\section{Research Article}

Keywords: E-learning, students' experience, virtual learning, Coronavirus pandemic

Posted Date: December 1st, 2020

DOl: https://doi.org/10.21203/rs.3.rs-117994/v1

License: (c) (i) This work is licensed under a Creative Commons Attribution 4.0 International License. Read Full License 


\section{Abstract}

The number of multimedia courseware developed to assist teaching and learning activities has increased tremendously, following the declaration of schools' closure during COVID-19 pandemic. This study aimed at e- learning experiences of 550 students of a medical school in Iran during the time Coronavirus pandemic hit Iran. To achieve the objectives of this study, a self-devised questionnaire was used, and the data were analyzed using Independent samples T. test, ANOVA, and MANOVA. Results have demonstrated that university students had a satisfactory e-learning experience during the lockdown with an exception for online synchronous classes. This study also showed that older students are more satisfied with elearning and that there was a significant difference between the overall mean score of those who had access to PCs and laptops compared to those who had accessed only to mobile phones. Our results also showed a significant difference exists between the e-learning experience of students who had experienced virtual classes prior to Covid-19 pandemic and those who had not; however, no significant difference was seen in terms of the residence of the students and their gender.

\section{Introduction}

Because of Coronavirus pandemic, pedagogical approaches in e-education have been utilized for many teachers and students all around the world. Therefore, the number of multimedia courseware developed to assist teaching and learning activities has increased tremendously, following the declaration of schools' closure during COVID-19 pandemic. Reportedly, although at the beginning, teachers and university lecturers had more difficulty adjusting to the new circumstances than school students and university ones, gradually teachers started to develop their digital skills by going beyond using Internet just for searching and started to design, format, make, and edit their own e-contents using various platforms previously had not experienced before. Students, equally, had to raise their digital literacy skills in order to locate and use various e-resources their teachers presented.

However, all this technological growth happened overnight for teachers and students alike, something which contradicts ' 10,000 hours to master a skill' rule of thumb many suggest. On the other hand, culturally and mentally, there had always been a disinclination towards e-learning on behalf of many teachers including for example professors teaching at Shiraz University of Medical Sciences (SUMS). Reportedly, although Shiraz Virtual University of Medical Sciences had been established 10 years prior to COVID-19 incidence, there were a few medical schools and faculty members who were actively involved in medical virtual education. After teachers being forced to shift from face-to-face education to the virtual one mostly unwillingly, we thought it is paramount to study medical students' viewpoints of e-learningbased medical education that SUMS professors provided to their students during the time Coronavirus pandemic hit Iran.

\section{E-learning}


Prior to Coronavirus crisis, e-learning had maintained its prominent position at educational settings, especially for medical education. As Howlett et al. (2009) define it, e-learning is the usage of electronic technology for delivering, supporting, and enhancing both learning and teaching; however, it also involves an active communication between a teacher and students. In case of medical universities, presenting students with clinical cases, images, videos, and synchronous and asynchronous course activities blended with face-to-face lectures in classrooms has long been established all over the world with various degrees. University infrastructure, teachers' technical skills and digital literacies, teachers' teaching load and, therefore, their tendency and inclination to digital environments, and institutional support and attitudes towards e-learning are all few reasons behind the success or failure of e-learning implementation at various medical universities (O'Doherty et al., 2018; Shachar et al., 2016; Muhannad, 2013; Nour et al., 2019). Likewise, students, studying at medical schools or else, have experienced variously based on their background, schools they attend to, their digital literacy, and e-learning resources as well as institutional support they receive while and after school among many others. In terms of Infrastructure, for example, in one study conducted by Koh et al. (2014), majority of Malaysian medical students possessed smart devices with medical apps installed on them, and they reportedly had positive feelings regarding the effectiveness of these apps on their studies. Notably, Wi-Fi and $3 \mathrm{G}$ services were provided to all these medical students within the university and hospital. However, in another study, Masika et al., (2015) reported that in Kenya the main challenges of using mobile devices and apps for medical education are lack of smart devices, sub-optimal internet access, cost of acquiring apps, and limited device memory.

Sometimes the positive or negative attitudes students have towards e-learning are universal. For example, it is widely believed that the negative attitudes of university lecturers towards technology-based education can indirectly cause technology-based education resistance among students which, in turn, can cause a series of challenges for students (Kyong-Jee, et al. 2017). Sometimes it is not the e-contents, per se, that cause challenges for students, but failure of communication between a teacher and his/her students and students with their peers that negatively influences students' productivity in e-learning (Jang and Kim, 2014). As Chapman and Mahlk (2004) point out latest educational technology does not necessarily enhance instruction or students' participation. Also Daniels et al. (2019) indicate that the way e-learning materials are presented to students has a significant effect on the effectiveness of the lesson being taught. Sometimes lack of time management and absence of self-regulation are reported as major factors affecting students' e-learning experience (Jarvela et al., 2018). Not telling students "when" to access the contents, according to Pedrotti and Nistor (2019), is left up to students who especially in fully presented on-line courses, due to time constraint and lack of effort regulation strategies, fail to strategically plan their e-learning activities during the course.

Pedagogically, heightened cognitive load as a result of teachers' ineffective teaching methods is another challenge repeatedly reported by students. Cognitive load theory (CLT) offers a general framework of learning and its association with working memory as well as long-term memory within an e-learning environment (Clark \& Mayer, 2007). Extraneous or ineffective cognitive load presents students with unnecessary information that inhibit students' ability to process new information and to create long-term 
memories (Lambert et al., 2009). As Uppal (2017) indicates, e-learning works only if teachers know how students learn.

Apart from human factors, another challenge that impedes e-learning is technological facilities. Not only at schools and universities, but also at homes, so many students do not have access to foundational technology services, software, and hardware to fully explore opportunities computer-based teaching provides to them (Nor \& Mohamad, 2013). Although it is assumed that in the $21^{\text {st }}$ century we might or should not face such challenges anymore, in so many developing countries, bandwidth and connectivity issues still cause a perennial hurdle for synchronous and asynchronous e-learning/teaching (Bower et al., 2015). Even cost of buying Internet packages might be the concern for many students studying in such countries (Nor \& Mohamad, 2013), which even now, during Coronavirus pandemic that all courses are presented online, this concern, undoubtedly, has aggravated.

\section{E-learning and COVID-19 pandemic}

Globally, many students have to receive their course contents virtually because of their schools' closure after the pandemic. This rapid adjustment to the current global phenomenon necessitates not only teachers but also students to adapt themselves to this new homeschooling system by pushing them to learn new digital skills and new learning and teaching strategies in a short run. As a result, any observations about the way the coronavirus pandemic is impacting e-learning should be the concern for many researchers at this stage. While online learning might be available, it is unlikely to be as effective as face-to-face teaching; those with less resources will disproportionately be disadvantaged due to many reasons, including lack of preparation in participation in online classes, technical issues and concerns, weak/interrupted internet signals during live lectures, lack of face-to-face interaction, lack of time management, and many more during Coronavirus pandemic.

Even before Coronavirus pandemic, there was little literature available on the effectiveness of asynchronous and synchronous e-learning in medical universities and previous studies show that perceived e- learning challenges have to do more with lack of technological facilities and the kind of Learning Management System (LMS) which is used in a particular school (Hadullo et al. 2018). Therefore, this study could be a significant contribution to knowledge in this area if we must understand the perceptions of students regarding inhibiting factors related to e-learning. Furthermore, e-learning is a relatively new innovation in the design of educational facilities at medical universities Iran, especially during Coronavirus pandemic during which the fast pace of transition from face-to-face classes to distance education could not really prepare the officials and university authorities to evolve their digital tools to ensure uninterrupted educational delivery to every one of the students.

\section{Purpose of the study}

Mainly, the purpose of this study was: 
1. To identify SUMS medical students' views of e-learning-based medical education during Coronavirus pandemic.

2. To see if there are any differences in the students' general views and their age, gender, residence, digital and computer literacy, type of digital device used, prior e-learning experience, and degree of study.

\section{Research Methodology}

\section{Research Design}

After taking approval from the Ethical Review Committee of the Shiraz University of Medical Sciences, a cross-sectional descriptive study was conducted in March 2020 on the students' perception of e-learning experiences during the semester coincided with Coronavirus pandemic.

\section{Population of the Study}

The target population of this study was all students studying at SUMS, at various disciplines. SUMS is a public medical school located in Shiraz, Iran. It is ranked as one of Iran's top medical universities and it includes 11 main schools dealing with various academic studies related to medical sciences. Before Coronavirus pandemic, students had none to medium level experience in the format of blended learning. Therefore, the experience of pure e-learning was a completely new experience for all students.

The sample size of this study was determined to include 507 subjects by means of Kergesi Morgan's Table and simple random sampling was applied to collect the data.

\section{Research Instrument}

To achieve the objectives of this study, a self-devised questionnaire was used. In order to design a questionnaire with wide diversity of perceptions regarding students' e-learning experiences, an online focus group of heterogeneous sample consisting of 5 students studying at different medical schools within SUMS as well as 5 faculty members were held while we were still in the Covid-19 quarantine. With the permission of the participants, the focus group was video-recorded and all the comments were later drafted and conclusions were drawn by the researchers of this study. Thirty items were extracted and were presented in the format of Six-Likert items from strongly agree down to strongly disagree. The questionnaire was divided into 2 parts. Part one comprised of demographic parameters such as gender, age, students' discipline of study, their degree level (Associate degrees, continuous bachelor and noncontinuous bachelor degrees, Master's and doctoral degrees, and professional doctorate degree (Doctor of Medicine, Dentistry, and Pharmacy)), residence, and their digital and computer literacy. Part two of the questionnaire was designed based on semantic and content linkages of all items in the questionnaire.

Six questions allocated to evaluate technological facilities factors; 5 questions were related to university technical support; 5 questions targeted asynchronous learning, 5 questions targeted synchronous virtual classes; 3 questions identified students' perceptions of quality of e-contents made by faculty members; 6 questions evaluated teacher-student interactions. Also 5 questions aimed at general feelings of students 
towards e-learning. The cutoff point score was considered 3.5 equivalent to $50 \%$ which showed that the average greater than 3.5 for each component shows students' satisfaction.

Furthermore, 2 close-ended questions were asked from students and they were asked to choose from a distinct set of pre-defined responses. Students were asked if they thought e-learning education they had during Coronavirus pandemic was a) interesting, or b) horrible; if they preferred using blended learning in the future compared to pure face-to-face medical education after the eradication of Coronavirus.

Furthermore, and 1 open ended-question was also asked from students to see what they have missed the most in the traditional learning environment.

\section{Validity and Reliability}

The validity of the questionnaire was assessed by calculating the Content Validity Index (CVI) and the Content Validity Ratio (CVR). To this end, ten experts in the fields of medical education (2), e-learning (2), medical sciences (4), and English Language (2) reviewed the questionnaire items. The CVI for each question was $0.90-1$ that demonstrated high agreement among the content experts and CVR=0.80-1. In addition to content validity, the face validity of the questionnaire was measured. Following this, eight questions were modified in terms of grammar and eloquence. The reliability of the questionnaire was also measured after sending the initial version of the questionnaire to 40 medical students. Using Cronbach's alpha for analysis, the findings indicated a high reliability (94.8\%). We also measured internal consistency reliability of all items in the questionnaire; out of 30 items in the questionnaire, 4 items were deleted using Cronbach's alpha if item deleted. As a result, the reliability increased to $97.6 \%$.

\section{Data Collection Procedures}

After this study was approved by Ethical Committee of SUMS (Ref.No. IR.SUMS.REC.1399.616), data collection began. This survey was conducted in June, 2020, and while we were collecting the data, we were still in quarantine as a result of Coronavirus pandemic. Therefore, to collect the data, an online survey was designed to be sent to all students studying at SUMS, using WhatsApp social media group faculty members had with their students. Privacy and anonymity of the participants and confidentiality of data were granted, and subjects' informed consent was obtained.

\section{Data Analysis}

The data were analyzed using the Statistical Package for the Social Sciences (SPSS Inc., Chicago, IL, USA) for windows (version 24). Demographic characteristics of the participants were calculated by descriptive statistics (frequency and percentage of frequency). The data were also analyzed by Independent samples T. test, MANOVA, and ANOVA.

\section{Results Of The Study}

Demographic and Profile Characteristics 
As shown in Table 1, the demographic and profile information regarding those 507 students who responded to the online survey indicates that $343(67.7 \%)$ were females and $164(32.3 \%)$ were males. The highest percentage of the respondents, 207 (40.8\%), was studying at a continuous bachelor degree, followed by 193 (38.1\%) professional doctorate degree, 79 (15.6\%) non-continuous bachelor degree, 16 (3.2\%) PhD, and finally12 (2.4\%) held Master's degree. Four hundred (78.9\%) respondents aged between $18-24$ years old; 107 (21.1\%) aged more than 24 , and the mean average of the respondents was $26.8 \pm$ 23.7. There were $222(43.8 \%)$ who were living in their hometowns at the time of quarantine and 258 (56.2\%) who were resided at the campus. From students' digital and computer literacy viewpoint, the results showed that $287(56.6 \%)$ respondents had low to average digital and computer literacy, and 368 (72.6\%) had a sufficient digital and computer literacy and had the knowledge and ability to use computers and related technology efficiently. Out of all the participants, $368(72.6 \%)$ had a personal laptop for their studies, $139(27.4 \%)$ only accessed their mobile phones or occasionally had access to friends' or family members' computers and laptops. There were $125(24.7 \%)$ who had experienced elearning prior to Covid-19, and $382(75.3 \%)$ had not had such an experience at all. Table 1 shows the number of students who participated in this study from various schools within SUMS.

Inferential statistics

The mean and standard deviation for the responses of the participants to the questionnaire items are illustrated in Table 2. The overall mean score of all items in the questionnaire regarding the medical students' views of e-learning education was satisfactory $(3.87 \pm 1.03, p<0.001)$. However, the findings indicate that all e-learning components except the satisfaction towards online classes $(p=0.14)$ have obtained a score of over $50 \%$.

Considering the age factor, the students were divided into two groups: 18 to 24 years and more than 24 . The results of the independent samples t-test showed a significant difference in the overall mean of the students' responses to the questionnaire items with respect to the age factor $(p=0.027)$. It means that the greater the age, the more satisfaction students experienced regarding e-learning education except for synchronous classes $(p=0.98)$, technological facilities $(p=0.39)$, and support $(p=.08)$ components in which no significant difference was identified.

In terms of gender, the results of the independent samples t-test indicate no significance difference between the opinions of the male and female students' e-learning experience $(p>0.05)$ not only in the overall mean but also in the sub-components.

The results also showed that there is a significant difference between the overall mean score of those who had access to PCs and laptops compared to those who had accessed only to mobile phones $(p=0.002)$. This difference was significant in terms of all the e-learning components.

Likewise, no significant difference was seen in terms of the residence of the students. However, a significant difference was observed in both the overall mean and the mean of each e-learning component 
in terms of students' computer and digital literacy. In other words, students' digital competence had a significant role in their adjustment to the virtual learning.

The results also showed that there is a significant difference between the students who had experienced virtual classes prior to Covid-19 pandemic and those who had not $(p=0.01)$. This difference was significant in terms of all the e-learning components except for asynchronous classes $(p=0.11)$.

Finally, we evaluated the relationship between students' degree (Associate degrees, continuous bachelor and non-continuous bachelor degrees, Master's and doctoral degrees, and professional doctorate degree) and their views of e-learning education. The results show that the students of dentistry, pharmacy, and medicine (professional doctorate degree) had a lower mean score than the undergraduates $(p=0.02)$, Master's students $(p=0.001)$, and PhD students $(p=0.03)$.

Since the investigated variables in the present study were in fact different facets of e-learning education, an interaction between them was assumed and MANOVA was used. For running MANOVA, at first, four indexes including Pillai's Trace, Hotelling's Trace, Roy's Largest Root, and Wilkes Lambda index were checked to ensure that the assumptions for conducting a MANOVA were not violated. The findings confirmed the interaction between the variables in the present study $(P=0.000)$.

As it can be seen in Table 8, the results of MANOVA showed that the impact of different factors on each other was significant. This implies that all of the factors had an impact on each other. Further investigations revealed that the teacher-learner interaction factor (Adjusted R Squared $=.060 ; F=4.23$ and using NAVID factor (Adjusted R Squared $=.050 ; F=3.69$ ) had the greatest impact on the students' desirability of e-learning education, respectively.

In terms of responses to close/open-ended questions, the results show that $322(67 \%)$ of students thought e-learning education is interesting; however, 302 students (60\%) preferred using blended learning in the future compared to $205(40 \%)$ reluctant students who preferred pure face-to-face medical education after the eradication of Coronavirus. Three hundred and fifty six students (75\%) believed the physical presence of the teacher sensed throughout the semester; likewise, 410 students (80\%) reported missing the peer-to-peer interaction they used to have in the traditional learning environment.

\section{Discussion And Conclusion}

Although a random sample of 507 students sought out to participate in this study, the findings and conclusions are limited in their generalizability because they were derived from only one medical university in Iran and most specifically the data were collected at the unusual time of Covid-19 pandemic, the time that results of any research is significantly overshadowed by the disease. Furthermore, because of the university closure, the data were collected only electronically, so perhaps students who did not have access to Internet could not fill out the questionnaire despite having negative views regarding e-learning education. With these caveats in mind, results have demonstrated that SUMS university students had a positive e-learning experience during the lockdown. This finding parallels another research carried out 
during the lockdown. Hyseni Duraku and Hoxha (2020) reported that although students faced challenges in terms of lack of attention in online classes due to various reasons, generally, they had a positive feeling towards e-learning not only because psychologically e-learning drew their attention away from the pandemic, but also because learning wise, they had more time for lessons and interactions with the professors. Our result is contradictory to another similar study conducted in Pakistan College of Medicine and Dentistry since the majority of the Pakistani students had a negative feeling towards elearning, were more inclined towards face-to-face learning in the future, and most importantly felt elearning had little impact on their learning in general during the pandemic (Abbasi, Ayoob, Malik, Memon, 2020). Considering medical students' e-learning experience literature before Covid-19, the results are mixed with a greater number of medical studies reporting students' positive feelings towards elearning (see for example, Ali, Jamil, Sethi, Ali, 2016; Singh \& Min, 2017; Attaran \& Zainuddin, 2018).

This study also revealed that SUMS students were dissatisfied with online synchronous classes perhaps because not all students could access synchronous classes reliably due to their geographical zone insufficient bandwidth, peer-to-peer traffic, and streaming of audio and video (Sanga, Kilima, \& Busagala, 2010).

In our study, lack of interaction with the professors was also mentioned as one of the reasons why students are dissatisfied with synchronous classes. In comparison with asynchronous classes, many studies reported that students prefer asynchronous classes over live class sessions as in the latter teachers do not have time to answer their questions and do not have the required skills to properly handle online classes (see for example, Jackson, Jones, \& Rodriguez, 2010; Callaway, 2012; Cole et al., 2014). A successful synchronous session requires four types of interactivity: learner-teacher interaction, learner-learner interaction, learner-content interaction and learner-interface interaction (Sims, 1999).

This study also showed that older students are more satisfied with e-learning. This finding does not support another study conducted in which it was reported that age is not a significant factor influencing both the future use intentions and satisfaction with e-learning (Fleming, Becker, and Newton, 2017). Another study carried out by Dabaj (2009) also reported similar finding. This result is interesting because it seems that younger generation is supposed to be more digital literate and more competent with elearning; however, it seems that in our study, experience and wisdom acquired by age has a more contributing role in e-learning acceptance especially at the time of over-night shift to virtual learning due to Covid-19 pandemic. McSporran and Young (2001) reported that because mature female students are better at scheduling their learning and are better at communicating online, they are more motivated towards distance learning; this finding is partly consistent with our result because we could not find any significant relationship between students' gender and their e-learning experience. This is supported by a study, which had been conducted in Malaysia (Rahman et al., 2012).

No significant difference was seen in terms of the residence of the students. In other words, living at home or residing in the hostel did not play any role in students' e-learning experience. However, our finding revealed that students' computer and digital literacy played a significant part in their e-learning 
experience. This finding parallels previous research in this area that students' digital literacy is a prerequisite for learning effectively in a blended learning environment (see Tang \& Chaw, 2016; Mohammadyari \& Singh, 2015). However, Concannon et al. (2005) believe that this is not the students' digital literacy that should be the main concern, but it is their attitude towards e-learning that matters the most. In their study, they reported that even the least digital literate students had a positive attitude towards e-learning and as a result none of students stated difficulties while using technologies. In contrast, Mohammadyari and Singh (2015) believe that digital literacy is not merely about having the computer knowledge; it is, instead, one of many other literacies people need, in the $21^{\text {st }}$ century, to understand and comprehend various type of information.

This study also revealed that a significant difference exists between the overall mean score of those who had access to PCs and laptops compared to those who had accessed only to mobile phones. This shows that the choice of hardware plays a significant role not only in students' e-learning experience in general, but also in all the sub-components of this study, content quality, interaction with teachers, and asynchronous classes, to name a few. From a synchronous classes and content quality, this result might be justifiable in terms that almost all the multimedia contents made during Covid-19 pandemic were not designed and developed for mobile users; they were simply made out of necessity. Therefore, while developing the contents, perhaps teachers did not consider the smaller screen of the mobile phone users and the type and the size of the fonts they were using. Sung, Chang, and Liu (2015) believe that teachers need teacher-development training to improve mobile-enhanced instruction. Insufficient preparation on behalf of teachers, according to Frohberg et al. (2009), is one of the major factors in students' learning failure using mobile devices. Although in our study, only about $28 \%$ accessed their mobile phones for studying and did not have any personal computers and laptops, teachers should customize their teaching program rather than "simply designing their own program around the use of technology" (Sung et al. 2015, p.266).

Our results also showed a significant difference exists between the e-learning experience of students who had experienced virtual classes prior to Covid-19 pandemic and those who had not. In other words, those students who had experienced blended learning before had a more positive e-learning experience during the semester presented during the pandemic. Interestingly, this difference was significant in terms of all the e-learning components except for the asynchronous classes. This is because only after the pandemic, SUMS launched Navid Academic Learning Management System for the multimedia contents to be uploaded by the teachers for the students and this experience was new to all the students studying at SUMS. Therefore, perhaps, unfamiliarity with the system and all its modules might be the reason why there was a significant relationship between all the e-learning components except for the Navid system. This result is supported by Shafiei Sarvestani, Mohammadi, Afshin, Raeisy (2019) who reported that students from Virtual School of SUMS reported that a large number of modules has led to increased application complexity.

Our result also demonstrated that there is a significant difference between students' degree (continuous bachelor and non-continuous bachelor degrees, Master's and doctoral degrees, and professional 
doctorate degree) and their views of e-learning education. It seems that the lower the degree, the more satisfied students were in terms of e-learning medical education.

Finally, further investigations revealed that the teacher-learner interaction factor and using NAVID factor had the greatest impact on the students' desirability of e-learning education, respectively.

We also reported that more than half of students thought e-learning education is interesting; however, $60 \%$ of the students preferred using blended learning in the future compared to $40 \%$ reluctant students who preferred pure face-to-face medical education after the eradication of Coronavirus. This result is not in line with what Dabaj and Basak (2008) reported that although students may choose to study in online courses, they still prefer the traditional courses.

\section{Implication of the Study}

This study holds clear implications for e-learning medical education in the future since having insight regarding medical students' views of e-learning could help teachers, course designers and university authorities to develop general principles and standards through a systematic model to design relevant elearning courses for medical students. Since it is not known when we get back to old normal and face-toface or blended learning education, the results of this study provide yet more evidence for curriculum designers or instructional coordinators to design and facilitate multimedia courses that are tailored to all students, especially those who do not have the opportunities everyone else might have. Our result also highlights the importance of professional development resources for teachers in order to support them build necessary skills for developing virtual contents and delivering remote teaching, which in turn help the students not only develop their academic abilities but also learn more independently at home.

\section{Suggestions for future research}

Although the findings of this study showed that medical students had positive views regarding e-learning education, longer experiments with larger samples need to be conducted in the future to further investigate the effectiveness of e-learning medical education, especially under normal circumstances. Furthermore, since teachers are the providers of this education, it is vital to study their viewpoints regarding e-learning.

\section{Declarations}

\section{Availability of data and materials}

The datasets used and/or analysed during the current study are available from the corresponding author on reasonable request.

\section{Competing interests}

The authors declare that they have no competing interests. 


\section{Funding}

Not applicable

\section{Authors' contributions}

L. KH devised the study concept and created the first and final draft of the study. E. N. devised the questionnaire and helped editing the final version of the manuscript. Z. K. ran the reliability and validity tests and analyzed the data, and S. Sh. collected the data.

\section{Acknowledgements}

Not applicable

\section{References}

Abbasi, S., Ayoob, T., Malik, A., Memon, SI. (2020). Perceptions of students regarding E-learning during Covid-19 at a private medical college. Pak J Med Sci. 36. doi: https://doi.org/10.12669/pjms.36.COVID19S4.2766

Ali, N., Jamil, B., Sethi, A., Ali, S. (2016). Attitude of nursing students towards e- learning. Adv Health Prof Educ. 2,24-29.

Attaran, M. \& Zainuddin, Z. (2018). How Students Experience Blended Learning? (Malaysian Experience). Interdisciplinary Journal of Virtual Learning in Medical Sciences, 9 (2). doi: 10.5812/ijvlms.79384

Bower, M., Dalgarno, B., Kennedy, G., Lee, M., \& Kenney, J., (2015). Design and implementation factors in blended synchronous learning environments: Outcomes from a cross-case analysis. Computers \& Education, 86, 1-17. https://doi.org/10.1016/j.compedu.2015.03.006

Callaway, S.K. (2012). Implications of online learning: Measuring student satisfaction and learning for online and traditional students. Insights to a Changing World Journal, 2, www.franklinpublishing.net

Cole, M.T., Shelley, D.J. \& Swartz, L.B. (2014). Online Instruction, E-Learning, and Student Satisfaction: A Three Year Study. The International Review of Research in Open and Distributed Learning, 15(6), 111-131. Retrieved from https://www.learntechlib.org/p/156200/.

Chapman, D., \& Mahlk, L. (2004). Adapting technology for school improvement: A global perspective. International Institute for Educational Planning. Retrieved from http://www.unesco.org/iiep/PDF/pubs/F165.pdf

Clark, R.C. \& Mayer, R. E. (2007). E-learning and the Science of Instruction. San Francisco: Pfeiffer. Concannon, F., Flynn, A., \& Campbell, M. (2005). What campus-based students think about the quality and benefits of e-learning. British Journal of Educational Technology, 36(3), 501-512. 
https://doi.org/10.1111/j.1467-8535.2005.00482.x.

Dabaj, F. (2009). The role of gender and age on students' perceptions towards online education. Case study: Sakarya University, Vocational High School. The Turkish Online Journal of Educational Technology, 8(2), 120-123.

Dabaj, F. \& Basak, H. (2008). The Role of Gender and Age on Students' Perceptions towards Online Education Case Study: Sakarya University, Vocational High School. World Academy of Science, Engineering and Technology. Retrived from

http://www.eric.ed.gov/ERICDocs/data/ericdocs2sql/content_storage_01/0000019b/80/44/01/ad.pdf. 16.12.2009.

Daniels, M. M., Sarte, E. \& Dela Cruz, J. (2019). Students' perception on e-learning: a basis for the development of e-learning framework in higher education institutions, The International Conference on Information Technology and Digital Applications, IOP Conf. Series: Materials Science and Engineering 482 (2019) 012008 IOP Publishing doi:10.1088/1757-899X/482/1/012008

Fleming, J., Becker, K. and Newton, C. (2017). Factors for successful e-learning: does age matter? Education + Training, 59 (1), 76-89. https://doi.org/10.1108/ET-07-2015-0057

Frohberg, D., Göth, C., Schwabe, G. (2009). Mobile learning projects-a critical analysis of the state of the art. Computer Assisted Learning, 25(4), 307-331. https://doi.org/10.1111/j.1365-2729.2009.00315.x

Hadullo, K., Oboko, R., \& Omwenga, E. (2018). Factors affecting asynchronous e-learning quality in developing countries university settings. International Journal of Education and Development using ICT, 14(1), 152-163. Retrieved from https://www.learntechlib.org/p/183551/

Howlett, D., Vincent, T., Gainsborough, N., Fairclough, J., Taylor, N., Vincent, R. (2009). Integration of a case-based online module into an undergraduate curriculum: what is involved and what is effective? $E$ Learning and Digital Media. 6 (4):372-84. https://journals.sagepub.com/doi/10.2304/elea.2009.6.4.372 Hrastinski, S. (2008). Asynchronous and synchronous e-learning. Educause quarterly, 31(4), 51-55.

Hyseni Duraku, Z., \& Hoxha, L. (2020). The impact of COVID-19 on higher education: A study of interaction among students' mental health, attitudes toward online learning, study skills, and changes in students' life. Retrieved from https://www.researchgate.net/publication/341599684

Jackson, L. C., Jones, S. J., \& Rodriguez, R. C. (2010). Faculty Actions that Result in Student Satisfaction in Online Courses, 14(4), 78-96. http://doi: 10.24059/olj.v14i4.129

Jang, HW. \& Kim, KJ. (2014). Use of online clinical videos for clinical skills training for medical students: benefits and challenges. BMC Med Educ. 14- 56. doi:10.1186/1472-6920-14-56 
Jarvela, S., Hadwin, A., Malmberg, J., Miller, M. (2018). Contemporary perspectives of regulated learning in collaboration. In: Fischer, F., Hmelo-Silver, C.E., Goldman, S.R., Reimann, P. (eds.) International Handbook of the Learning Sciences, pp. 127-136. Routledge, New York

Kwee Choy Koh, M. Wan, J. K., Selvanathan, S. Vivekananda, C. Lee. G.Y., Ng, C.T. (2014). Medical students' perceptions regarding the impact of mobile medical applications on their clinical practice. Journal MTM, 3(1), 46-53, 201. http://doi:10.7309/jmtm.3.1.7

Kyong-Jee, K., Youngjoon, K., \& Giwoon, kim (2017). The gap between medical faculty's perceptions and use of e-learning resources, Medical Education Online, 22, 1338504 https://doi.org/10.1080/10872981.2017.1338504

Lambert, J., kalyuga, S., Capan, L. (2009). Student Perceptions and Cognitive Load: what can they tell us about e-learning Web 2.0 course design? E-Learning, 6(2). http://doi: 10.2304/elea.2009.6.2.150

Masika, M. M., Omondi, G. B., Natembeya, D. S., Mugane, E. M., Bosire, K. O., \& Kibwage, I. O. (2015). Use of Mobile Learning Technology among Final Year Medical Students in Kenya. Pan African Medical Journal, 21, 127. https://doi.org/10.11604/pamj.2015.21.127.6185

McBrien, J. L., Cheng, R., \& Jones, P. (2009). Virtual spaces: Employing a synchronous online classroom to facilitate student engagement in online learning. The International Review of Research in Open and Distributed Learning, 10(3).

McSporran, M. \& Young, S. (2001). Does gender matter in online learning?, ALT-J, 9(2), 3-15, DOI: $10.1080 / 0968776010090202$

Mohammadyari, S., and Singh, H. 2015. "Understanding the effect of e-learning on individual performance: The role of digital literacy," Computers and Education (82), pp. 11-25. DOI: 10.1016/j.compedu.2014.10.025

Muhannad, A-SH. (2013). The Level of E-Learning Integration at the University of Jordan: Challenges and Opportunities. International Education Studies, 6(4), 93-113. https://doi:10.5539/ies.v6n4p93

Murphy, E., Rodríguez-Manzanares, M. A., \& Barbour, M. (2011). Asynchronous and synchronous online teaching: Perspectives of Canadian high school distance education teachers. British Journal of Educational Technology, 42(4), 583-591.

Nour, AJ., Samina, Sh., Sabrina, M., Saleha, M. \& Afshan, Khan. (2019). Development of e-learning in medical education: a student's perspective, Korean J Med Educ, 31(4), 371-373. https://doi.org/10.3946/kjme.2019.147

Nor, M. Z., \& Mohamad, A. M. (2013). Challenges in Accepting the E-Learning System: The Case of ELearners from Different Backgrounds of Study. 3rd International Conference For e-Learning \& Distance Education, 1-14. 
O’Doherty, D., Dromey, M., Lougheed, J., Hannigan, A., Last, J., McGrath, D. Barriers and solutions to online learning in medical education: an integrative review. BMC Med Educ. 2018; 18(1):130.

https://doi.org/10.1186/s12909-018-1240-0

Parsad, B. \& Lewis, L. (2008). Distance Education at Degree-Granting Postsecondary Institutions: 200607 (NCES 2009-044). Washington, DC: National Center for Education Statistics, Institute of Education Sciences, U.S. Department of Education.

Pedrotti M., Nistor N. (2019) How Students Fail to Self-regulate Their Online Learning Experience. In: Scheffel M., Broisin J., Pammer-Schindler V., Ioannou A., Schneider J. (eds) Transforming Learning with Meaningful Technologies. EC-TEL 2019. Lecture Notes in Computer Science, vol 11722. Springer, Cham

Rahman, S. Ahmad, S. Ismail, Kh., Mastor, K. A. (2012) Gender, field of study, and total learning experience: implications for teaching and learning. Social and Behavioral Sciences, 46, $4849-4852$. Retrieved from https://www.sciencedirect.com/science/article/pii/S1877042812020836/pdf? md5=ee7e793bc1684a9afa12b6956c03359b\&pid=1-s2.0-S1877042812020836-main.pdf\&_valck=1

Salmon, G. (2013). E-tivities: The key to active online learning. Routledge.

Sanga, C., Kilima, J., Busagala, L. (2010). Optimizing Internet Bandwidth in Higher Learning Institutions: A Case of Sokoine University of Agriculture. International Journal of Computing and ICT Research, 4(2), 2736. http://www.ijcir.org/volume 4-number2/article3.pdf.

Shachar, M., \& Neumann, Y. Differences between traditional and distance education academic performances: a meta-analytic approach. The International Review of Research in Open and Distributed Learning. 4(2). DOI: https://doi.org/10.19173/irrodl.v4i2.153

Shafiei Sarvestani, M., Mohammadi, M. Afshin, J., Raeisy, L. (2019) Students' Experiences of E-Learning Challenges; a Phenomenological Study. Interdisciplinary Journal of Virtual Learning in Medical Sciences, 10 (3), 1-10. Doi.10.30476/ijvlms.2019.45841

Sims, R. (1999). Interactivity on stage: Strategies for learner-designer communication. Australian Journal of Educational Technology, 15(3), 257-272. https://doi.org/10.14742/ajet

Singh, A., \& Min, AK. (2017). Digital lectures for learning gross anatomy: a study of their efficacy. Korean J Med Educ. 29, 27-32. doi: 10.3946/kjme.2017.50

Somenarain, L., Akkaraju, S., \& Gharbaran, R. (2010). Student perceptions and learning outcomes in asynchronous and synchronous online learning environments in a biology course. Journal of Online Learning and Teaching, 6(2), 353-356.

Sung YT, Chang KE, Liu TC. The effects of integrating mobile devices with teaching and learning on students' learning performance: A meta-analysis and research synthesis. Computers \& Education, 1(94), 252-75. https:// doi.org/10.1016/j.compedu.2015.11.008 
Swan, K. (2001). Virtual interaction: Design factors affecting student satisfaction and perceived learning in asynchronous online courses. Distance Education, 22(2), 306-331.

Tang, C. M. \& Chaw, L. Y. (2016). Digital Literacy: A Prerequisite for Effective Learning in a Blended Learning Environment? Electron. J. E-Learn, 14(1), 54-65, 2016. Retrieved from https://www.researchgate.net/publication/343349523_ELearning_Development_for_Special_Education_Postgraduate_Students

Teng, D. C. E., Chen, N. S., Kinshuk \& Leo, T. (2012). Exploring students' learning experience in an international online research seminar in the Synchronous Cyber Classroom. Computers \& Education, 58(3), 918-930.

Uppal, M. A. (2017) Addressing student perception of E-learning challenges in Higher Education holistic quality approach. PhD thesis, University of Reading. Retrieved from http://centaur.reading.ac.uk/75746/

\section{Tables}

Table 1 Frequency and Percent of Respondents

\begin{tabular}{|l|c|c|}
\hline \multicolumn{1}{|c|}{ School } & Frequency & Valid Percent \\
\hline Medicine & 121 & 23.9 \\
\hline Dentistry & 37 & 7.3 \\
\hline Pharmacology & 54 & 10.7 \\
\hline Nursing & 71 & 14.0 \\
\hline Paramedicine & 72 & 14.2 \\
\hline Rehabilitation Sciences & 33 & 6.5 \\
\hline Health & 53 & 10.5 \\
\hline Nutrition and Food Sciences & 66 & 13.0 \\
\hline Total & 507 & 100.0 \\
\hline
\end{tabular}

Table 2 The mean and standard deviation for the responses of the participants to the questionnaire items 


\begin{tabular}{|c|c|c|c|c|c|c|c|}
\hline \multirow[b]{2}{*}{ Components } & \multirow[b]{2}{*}{ Items } & \multicolumn{3}{|c|}{ Items } & \multicolumn{3}{|c|}{ Components } \\
\hline & & $\mathrm{N}$ & Mean & SD & Mean+SD & $\mathrm{t}$ & Sig \\
\hline \multirow[t]{5}{*}{$\begin{array}{l}\text { Technological } \\
\text { facilities }\end{array}$} & $\begin{array}{l}\text { I had access to a computer or mobile phone to learn via the } \\
\text { virtual system. }\end{array}$ & 504 & 5.13 & 1.16 & \multirow[t]{5}{*}{$4.29 \pm 1.13$} & \multirow[t]{5}{*}{15.23} & \multirow[t]{5}{*}{0.000} \\
\hline & $\begin{array}{l}\text { 2. When downloading my offline video contents, I did not } \\
\text { face any problems in terms of network and the Internet }\end{array}$ & 499 & 4.01 & 1.66 & & & \\
\hline & $\begin{array}{l}\text { 3. when having online classes, I did not face any problems } \\
\text { in terms of network and the Internet }\end{array}$ & 481 & 3.53 & 1.68 & & & \\
\hline & $\begin{array}{l}\text { 4. My computer hardware and software settings were } \\
\text { suitable for e-learning }\end{array}$ & 506 & 4.51 & 1.40 & & & \\
\hline & $\begin{array}{l}\text { 5. I did not face any problems to access Navid (LMS) in } \\
\text { terms of authentication }\end{array}$ & 506 & 4.38 & 1.67 & & & \\
\hline \multirow[t]{4}{*}{$\begin{array}{l}\text { Technical } \\
\text { support }\end{array}$} & $\begin{array}{l}\text { 6. Despite the suspension of classes, the technical } \\
\text { infrastructure was able to maintain trainings }\end{array}$ & 504 & 3.52 & 1.61 & \multirow[t]{4}{*}{$4.00 \pm 1.08$} & \multirow[t]{4}{*}{10.12} & \multirow[t]{4}{*}{0.000} \\
\hline & $\begin{array}{l}\text { 7. Training guidelines were provided on how to use the } \\
\text { virtual systems }\end{array}$ & 503 & 4.20 & 1.36 & & & \\
\hline & $\begin{array}{l}\text { 8. I received the necessary information and support } \\
\text { through the faculty and university to attend the virtual } \\
\text { classes }\end{array}$ & 471 & 3.82 & 1.35 & & & \\
\hline & $\begin{array}{l}\text { 9. Necessary software was introduced for using websites } \\
\text { and virtual classes }\end{array}$ & 505 & 4.53 & 1.27 & & & \\
\hline \multirow[t]{4}{*}{$\begin{array}{l}\text { Asynchronous } \\
\quad \text { learning }\end{array}$} & $\begin{array}{l}10 . \text { Working with different parts of Navid system (offline) } \\
\text { was easy }\end{array}$ & 505 & 4.47 & 1.23 & \multirow[t]{4}{*}{$3.73 \pm 1.20$} & \multirow[t]{4}{*}{4.25} & \multirow[t]{4}{*}{0.000} \\
\hline & $\begin{array}{l}\text { 11. Navid system was a proper platform for receiving } \\
\text { lessons and assignments }\end{array}$ & 506 & 4.09 & 1.42 & & & \\
\hline & $\begin{array}{l}\text { 12. Navid system was a proper platform for quizzes and } \\
\text { exams }\end{array}$ & 477 & 3.38 & 1.68 & & & \\
\hline & $\begin{array}{l}\text { 13. The lessons were presented in a planned, regular, and } \\
\text { sequential manner }\end{array}$ & 507 & 3.01 & 1.72 & & & \\
\hline \multirow[t]{4}{*}{$\begin{array}{l}\text { Synchronous } \\
\text { learning }\end{array}$} & $\begin{array}{l}\text { 14. The virtual system was a proper platform for providing } \\
\text { online classes }\end{array}$ & 479 & 3.54 & 1.56 & \multirow[t]{4}{*}{$3.59 \pm 1.31$} & \multirow[t]{4}{*}{1.46} & \multirow[t]{4}{*}{0.14} \\
\hline & $\begin{array}{l}\text { 15. I had no particular problem for entering the online } \\
\text { classes }\end{array}$ & 467 & 3.77 & 1.62 & & & \\
\hline & $\begin{array}{l}\text { 16. I could raise my own questions in online classes with } \\
\text { the professor }\end{array}$ & 458 & 3.49 & 1.63 & & & \\
\hline & $\begin{array}{l}\text { 17. Getting connected and attending the online classes was } \\
\text { easy for me }\end{array}$ & 467 & 3.53 & 1.60 & & & \\
\hline \multirow[t]{3}{*}{$\begin{array}{l}\text { Content } \\
\text { quality }\end{array}$} & $\begin{array}{l}\text { 18. The electronic contents presented by the professors } \\
\text { were understandable and informative }\end{array}$ & 500 & 3.87 & 1.48 & \multirow[t]{3}{*}{$3.84 \pm 1.05$} & \multirow[t]{3}{*}{6.10} & \multirow[t]{3}{*}{0.000} \\
\hline & $\begin{array}{l}\text { 19. In the current situation, electronic contents were rich } \\
\text { enough to make up for the absence of a professor and the } \\
\text { absence of face-to-face classes }\end{array}$ & 504 & 3.54 & 1.57 & & & \\
\hline & $\begin{array}{l}\text { 20. Presenting lessons in the form of electronic content was } \\
\text { very interesting and effective in motivating me }\end{array}$ & 500 & 3.47 & 1.66 & & & \\
\hline \multirow{4}{*}{$\begin{array}{l}\text { Teacher- } \\
\text { learner } \\
\text { interaction }\end{array}$} & $\begin{array}{l}\text { 21. I could stay in touch with my professors through Navid } \\
\text { system modules (conversations and forums) }\end{array}$ & 504 & 3.60 & 1.52 & \multirow[t]{4}{*}{$3.63 \pm 1.32$} & \multirow[t]{4}{*}{2.06} & \multirow[t]{4}{*}{0.04} \\
\hline & $\begin{array}{l}\text { 22. I was able to stay in touch with my professors through } \\
\text { online virtual classes }\end{array}$ & 468 & 3.37 & 1.54 & & & \\
\hline & $\begin{array}{l}\text { 23. I was able to stay in touch with my professor through } \\
\text { social media }\end{array}$ & 495 & 3.63 & 1.58 & & & \\
\hline & $\begin{array}{l}\text { 24. My professors provided quick and efficient feedback to } \\
\text { my educational needs and questions. }\end{array}$ & 471 & 3.62 & 1.54 & & & \\
\hline
\end{tabular}

Page $17 / 20$ 


\begin{tabular}{|l|l|l|l|l|l|l|} 
& $\begin{array}{l}\text { 25. My professors encouraged me to interact and } \\
\text { participate in lessons and discussions }\end{array}$ & 465 & 3.64 & 1.53 & & \\
\cline { 2 - 5 } & $\begin{array}{l}\text { After doing the assignments, I received feedback from my } \\
\text { professors. }\end{array}$ & 463 & 3.63 & 1.54 & & \\
\hline Total & & $3.87 \pm 1.03$ & 6.77 & 0.000 \\
\hline
\end{tabular}

Table 3 The relationship between students' responses to the questionnaire items with respect to the age factor

\begin{tabular}{|c|c|c|c|c|c|c|}
\hline Components & Age & $\mathrm{N}$ & Mean & Std. D & $\mathrm{t}$ & Sig \\
\hline Technological facilities & $18-24$ & 370 & 4.32 & 1.15 & 0.85 & 0.39 \\
\cline { 2 - 6 } & $>24$ & 99 & 4.21 & 1.07 & & \\
\hline \multirow{2}{*}{ Technical support } & $18-24$ & 364 & 3.96 & 1.08 & -1.72 & 0.08 \\
\cline { 2 - 6 } & $>24$ & 103 & 4.17 & 1.04 & & \\
\hline Asynchronous learning & $18-24$ & 375 & 3.60 & 1.22 & -4.69 & 0.000 \\
\cline { 2 - 6 } & $>24$ & 100 & 4.23 & 0.99 & & \\
\hline Synchronous learning & $18-24$ & 339 & 3.59 & 1.32 & -0.02 & 0.98 \\
\cline { 2 - 6 } & $>24$ & 96 & 3.59 & 1.30 & & \\
\hline Content quality & $18-24$ & 274 & 3.76 & 1.06 & -2.48 & 0.01 \\
\cline { 2 - 6 } & $>24$ & 83 & 4.09 & 0.96 & & \\
\hline Teacher-learner interaction & $18-24$ & 326 & 3.52 & 1.33 & -3.12 & 0.002 \\
\cline { 2 - 6 } & $>24$ & 96 & 4.00 & 1.22 & & \\
\hline Total & $18-24$ & 274 & 3.80 & 1.04 & -2.22 & 0.027 \\
\cline { 2 - 5 } & $>24$ & 83 & 4.09 & 0.94 & & \\
\hline
\end{tabular}

Table 4 students' digital competence role in students' adjustment to the virtual learning

\begin{tabular}{|c|c|c|c|c|c|c|}
\hline Components & Students' digital competence & $\mathrm{N}$ & Mean & Std. D & $\mathrm{t}$ & Sig \\
\hline \multirow[t]{2}{*}{ Technological facilities } & Low/ to some extent & 269 & 3.95 & 1.09 & \multirow[b]{2}{*}{-8.16} & \multirow[b]{2}{*}{0.000} \\
\hline & Expert & 200 & 4.76 & 1.01 & & \\
\hline \multirow[t]{2}{*}{ Technical support } & Low/ to some extent & 271 & 3.78 & 1.01 & \multirow[b]{2}{*}{-5.37} & \multirow[b]{2}{*}{0.000} \\
\hline & Expert & 196 & 4.31 & 1.10 & & \\
\hline \multirow[t]{2}{*}{ Asynchronous learning } & Low/ to some extent & 274 & 3.54 & 1.18 & \multirow[b]{2}{*}{-4.19} & \multirow[b]{2}{*}{0.000} \\
\hline & Expert & 201 & 4.00 & 1.19 & & \\
\hline \multirow[t]{2}{*}{ Synchronous learning } & Low/ to some extent & 256 & 3.31 & 1.24 & \multirow[b]{2}{*}{-5.49} & \multirow[b]{2}{*}{0.000} \\
\hline & Expert & 179 & 3.99 & 1.32 & & \\
\hline \multirow[t]{2}{*}{ Content quality } & Low/ to some extent & 215 & 3.58 & 0.97 & \multirow[b]{2}{*}{-5.89} & \multirow[b]{2}{*}{0.000} \\
\hline & Expert & 142 & 4.22 & 1.04 & & \\
\hline Teacher-learner interaction & Low/ to some extent & 248 & 3.51 & 1.23 & -2.29 & 0.023 \\
\hline
\end{tabular}

Table 5 The relationship between students' access to computers/laptops/mobile phones and virtual learning 


\begin{tabular}{|c|c|c|c|c|c|c|}
\hline Components & Computer access & $\mathrm{N}$ & Mean & Std. D & $\mathrm{t}$ & Sig \\
\hline \multirow[t]{2}{*}{ Technological facilities } & No-PC/Lap & 126 & 3.68 & 1.14 & & \multirow[t]{2}{*}{0.000} \\
\hline & PC/Lap & 343 & 4.52 & 1.04 & -7.56 & \\
\hline \multirow[t]{2}{*}{ Technical support } & No-PC/Lap & 135 & 3.84 & 1.03 & & \multirow[b]{2}{*}{0.04} \\
\hline & PC/Lap & 332 & 4.07 & 1.09 & -2.05 & \\
\hline \multirow[t]{2}{*}{ Asynchronous learning } & No-PC/Lap & 136 & 3.65 & 1.15 & \multirow[b]{2}{*}{-1.01} & \\
\hline & PC/Lap & 339 & 3.77 & 1.22 & & \\
\hline \multirow[t]{2}{*}{ Synchronous learning } & No-PC/Lap & 128 & 3.29 & 1.22 & \multirow[b]{2}{*}{-3.12} & \multirow[b]{2}{*}{0.002} \\
\hline & PC/Lap & 307 & 3.72 & 1.33 & & \\
\hline \multirow[t]{2}{*}{ Content quality } & No-PC/Lap & 113 & 3.59 & 0.96 & \multirow[b]{2}{*}{-3.06} & \multirow[b]{2}{*}{0.002} \\
\hline & PC/Lap & 244 & 3.95 & 1.07 & & \\
\hline \multirow[t]{2}{*}{ Teacher-learner interaction } & No-PC/Lap & 125 & 3.61 & 1.19 & \multirow[b]{2}{*}{-0.23} & \multirow[t]{2}{*}{0.817} \\
\hline & PC/Lap & 297 & 3.64 & 1.38 & & \\
\hline \multirow[t]{2}{*}{ Total } & No-PC/Lap & 113 & 3.62 & 0.95 & \multirow[b]{2}{*}{-3.12} & \multirow[b]{2}{*}{0.002} \\
\hline & PC/Lap & 244 & 3.98 & 1.04 & & \\
\hline
\end{tabular}

Table 6 The relationship between students' prior e-learning experience and their current experience

\begin{tabular}{|c|c|c|c|c|c|c|}
\hline Components & Prior experience & $\mathrm{N}$ & Mean & Std. D & $\mathrm{t}$ & Sig \\
\hline \multirow[t]{2}{*}{ Technological facilities } & No & 357 & 4.17 & 1.12 & \multirow[b]{2}{*}{-4.29} & \multirow[b]{2}{*}{0.00} \\
\hline & Yes & 112 & 4.69 & 1.07 & & \\
\hline \multirow[t]{2}{*}{ Technical support } & No & 356 & 3.91 & 1.06 & \multirow[b]{2}{*}{-3.27} & \multirow[b]{2}{*}{0.00} \\
\hline & Yes & 111 & 4.29 & 1.10 & & \\
\hline \multirow[t]{2}{*}{ Asynchronous learning } & No & 366 & 3.69 & 1.17 & \multirow[b]{2}{*}{-1.61} & \multirow[b]{2}{*}{0.11} \\
\hline & Yes & 109 & 3.90 & 1.30 & & \\
\hline \multirow[t]{2}{*}{ Synchronous learning } & No & 332 & 3.48 & 1.27 & \multirow[b]{2}{*}{-3.08} & \multirow[b]{2}{*}{0.00} \\
\hline & Yes & 103 & 3.94 & 1.38 & & \\
\hline \multirow[t]{2}{*}{ Content quality } & No & 281 & 3.76 & 1.01 & \multirow[b]{2}{*}{-2.65} & \multirow[b]{2}{*}{0.01} \\
\hline & Yes & 76 & 4.12 & 1.13 & & \\
\hline \multirow[t]{2}{*}{ Teacher-learner interaction } & No & 327 & 3.57 & 1.27 & \multirow[b]{2}{*}{-1.66} & \multirow[b]{2}{*}{0.10} \\
\hline & Yes & 95 & 3.83 & 1.49 & & \\
\hline \multirow[t]{2}{*}{ Total } & No & 281 & 3.80 & 0.99 & \multirow[b]{2}{*}{-2.49} & \multirow[b]{2}{*}{0.01} \\
\hline & Yes & 76 & 4.13 & 1.12 & & \\
\hline
\end{tabular}

Table 7 Between-subjects factors

\begin{tabular}{|l|l|c|c|c|c|}
\hline Effect & Value & $F$ & Error df & Sig. \\
\hline School & Pillai's Trace & .359 & 3.171 & 2094.000 & .000 \\
\cline { 2 - 6 } & Wilks' Lambda & .683 & 3.264 & 1616.955 & .000 \\
\cline { 2 - 6 } & Hotelling's Trace & .407 & 3.317 & 2054.000 & .000 \\
\cline { 2 - 6 } & Roy's Largest Root & .197 & $9.827^{\mathrm{C}}$ & 349.000 & .000 \\
\hline
\end{tabular}

Table 8 The interaction between the components of e-learning education 


\begin{tabular}{|c|c|c|c|c|c|c|}
\hline Components & $\begin{array}{l}\text { Dependent } \\
\text { Variable }\end{array}$ & $\begin{array}{l}\text { Type III Sum of } \\
\text { Squares }\end{array}$ & $\mathrm{df}$ & $\begin{array}{c}\text { Mean } \\
\text { Square }\end{array}$ & $\mathrm{F}$ & Sig. \\
\hline \multirow[t]{3}{*}{ Technological support } & Corrected Model & 24.61 & 7 & 3.51 & 2.76 & .008 \\
\hline & \begin{tabular}{|l|} 
Error \\
\end{tabular} & 444.50 & 349 & 1.27 & \multirow{2}{*}{\multicolumn{2}{|c|}{$\begin{array}{c}\text { (Adjusted R Squared }= \\
.033)\end{array}$}} \\
\hline & Total & 6759.88 & 357 & - & & \\
\hline \multirow[t]{3}{*}{ Technical support } & Corrected Model & 18.69 & 7 & 2.67 & 2.35 & .023 \\
\hline & Error & 396.40 & 349 & 1.13 & \multirow{2}{*}{\multicolumn{2}{|c|}{$\begin{array}{c}\text { (Adjusted R Squared }= \\
.026)\end{array}$}} \\
\hline & Total & 6265.93 & 357 & - & & \\
\hline \multirow[t]{3}{*}{ Asynchronous learning } & Corrected Model & 37.53 & 7 & 5.36 & 3.69 & .001 \\
\hline & \begin{tabular}{|l|} 
Error \\
\end{tabular} & 506.92 & 349 & 1.45 & \multirow{2}{*}{\multicolumn{2}{|c|}{$\begin{array}{c}\text { (Adjusted R Squared }= \\
.050)\end{array}$}} \\
\hline & Total & 5734.93 & 357 & - & & \\
\hline \multirow[t]{3}{*}{ Synchronous learning } & Corrected Model & 27.53 & 7 & 3.93 & 2.35 & .023 \\
\hline & Error & 582.38 & 349 & 1.66 & \multirow{2}{*}{\multicolumn{2}{|c|}{$\begin{array}{c}\text { (Adjusted R Squared }= \\
.026)\end{array}$}} \\
\hline & Total & 5276.68 & 357 & - & & \\
\hline \multirow[t]{3}{*}{ Content quality } & Corrected Model & 17.63 & 7 & 2.51 & 2.35 & .023 \\
\hline & Error & 373.09 & 349 & 1.06 & \multirow{2}{*}{\multicolumn{2}{|c|}{$\begin{array}{c}\text { (Adjusted R Squared }= \\
.026)\end{array}$}} \\
\hline & Total & 5649.24 & 357 & - & & \\
\hline \multirow{3}{*}{$\begin{array}{l}\text { Teacher-learner } \\
\text { interaction }\end{array}$} & Corrected Model & 45.41 & 7 & 6.48 & 4.23 & .000 \\
\hline & Error & 534.89 & 349 & 1.53 & \multirow{2}{*}{\multicolumn{2}{|c|}{$\begin{array}{c}\text { (Adjusted R Squared }= \\
.060)\end{array}$}} \\
\hline & Total & 5448.66 & 357 & - & & \\
\hline
\end{tabular}

